\title{
The Fortification of Biscuits with Coriander Leaf Powder and its Effect on Physico-Chemical, Antioxidant, Nutritional and Organoleptic Characteristics
}

\author{
DeEpali Mohite ${ }^{\mathrm{a}}$ And Roji Waghmare ${ }^{\mathrm{a}^{*}}$ \\ ${ }^{a}$ Food Science and Technology, School of Biotechnology and Bioinformatics, D. Y. Patil University, Navi \\ Mumbai, India \\ ${ }^{*}$ Corresponding author \\ roji.waghmare@dypatil.edu \\ TEL: +91 $7709467102(\mathrm{M})$
}

Received: 12 December 2018; Published online: 18 April 2020

\begin{abstract}
The aim of this study was to examine the effects of coriander powder substitutions at various proportions in biscuits. The coriander leaf powder (CLP) was rich in essential minerals like calcium $(2805.46 \mathrm{mg} / 100 \mathrm{~g})$, iron $(42.1 \mathrm{mg} / 100 \mathrm{~g})$ and phosphorous $(44.36 \mathrm{mg} / 100 \mathrm{~g})$. The scavenging activity of CLP was $93.34 \%$ and the total phenolic content was found to be $40.43 \mu \mathrm{g} / \mathrm{ml} \mathrm{GAE}$. The biscuits were prepared using 10, 20 and $30 \% \mathrm{CLP}$ and were baked at $180{ }^{\circ} \mathrm{C}$ for 17 minutes. Biscuits were evaluated for their nutritional composition, antioxidant activities, phenolic content, texture, sensory quality and shelf life over 21 days. The macronutrients, antioxidant activities, phenolic content and hardness increased with increasing concentrations of coriander powder. According to the overall acceptability scores from sensory evaluation, $10 \%$ and $20 \%$ CLP supplemented biscuits were more acceptable than $30 \%$ CLP supplemented biscuits.
\end{abstract}

Keywords: Biscuits; Coriander powder; Antioxidant activity; Shelf life; Fortification

\section{Introduction}

Coriander (Coriandrum sativum) is a member of the carrot family (Umbelliferae), and is considered an annual herb and a spice, since both its leaves and seeds are used as a seasoning. The root, stem, leaves and fruits all have a pleasant aromatic odour, and are widely used in flavorings. Leaves are particularly rich in vitamin $\mathrm{A}$, vitamin $\mathrm{C}$ and vitamin $\mathrm{K}$, with moderate content of dietary minerals (Dhanapakiam, Joseph, Ramaswamy, Moorthi \& Kumar, 2008). Coriander is a valuable herb in promoting digestion and treating gastro-intestinal disorders such as dyspepsia, flatulence, loss of appetite, griping pain and vomiting (Jabeen, Bashir, Ly- oussi \& Gilani, 2009). Dry coriander treats diarrhoea and chronic dysentery, as well as being useful in preventing acidity (Kaium, 2013). The seeds in particular are recommended as a cure for anxiety and insomnia (Emamghoreishi \& Heidari-Hamedani, 2005). Various parts of this plant such as leaves, flower seed, and fruit possess antioxidant activity, diuretic, anti-diabetic, sedative, anti-microbial activity, anti-convulsant activity, hypnotic activity, anti-helminthic and anti-mutagenic activity (Aissaoui, Zizi, Israili \& Lyoussi, 2011; Rajeshwari \& Andallu, 2011). Polyphenolic compounds, caffeic acid, protocatechinic acid and glycitin are present in high concentration in coriander aerial parts (Melo, Mancini \& Guerra, 2005). They are known 
to be excellent antioxidants. It has been demonstrated that coriander extract was able to decrease hyperglycemia and increase glucose uptake and metabolism, and insulin secretion (Jelodar, Mohsen \& Shahram, 2007). It was observed that incorporation of coriander in the diet lowered the LDL (Low density lipoprotein) and VLDL (Very low density lipoprotein), and significantly increased the HDL (High density lipoprotein) (Dhanapakiam et al., 2008).

The bakery industry in India is growing very rapidly and its products are very popular. Biscuits are the products which have attractive features, with wider consumption, relatively longer shelf life and good eating quality (Hooda \& Jood, 2005; Krystyjan, Gumul, Ziobro \& Korus, 2015). Biscuits are basically thin, flat and baked products made from flour, salt, sweetening agents, fat and food additives. As far as palatability is concerned, serious consideration is given to shelf life. Development of fortified biscuits or other composite flour bakery products is the latest trend in the bakery industry. Most of the bakery products are used as a source for incorporation of different nutritionally rich ingredients for their diversification (Hooda \& Jood, 2005). In recent years, there is a considerable body of research on biscuit ingredients and their proportions which could be modified to make biscuits more nutritious and healthy (Galla, Pamidighantam, Karakala, Gurusiddaiah \& Akula, 2017; Giarnetti, Paradiso, Caponio, Summo \& Pasqualone, 2015; Pasqualone, Bianco \& Paradiso, 2013; Yamsaengsung, Berghofer \& Schoenlechner, 2012).

In India, green leafy vegetables are common and are considered most economical because they are available throughout the year. The present dietary scenario necessitates the possible exploration of incorporating novel ingredients in commonly consumed foods rather than developing new food products. As the demands for nutritious food is increasing, efforts are needed to enhance the nutritional value of biscuits (Zaker, Aleem \& T. R., 2012).

The present work aims to estimate the nutritional composition and antioxidant activity of coriander leaf powder. The incorporation of CLP to formulate cost effective nutritionally enriched biscuits was followed by the analysis of the bis- cuit products in terms of nutritive value, microbial safety, sensory characteristics and shelf life over 21 days.

\section{Materials and Methods}

\subsection{Raw materials}

Whole coriander leaves were purchased from a local vegetable market in Navi Mumbai. Whole wheat flour, butter, sugar, vanilla essence, sodium bicarbonate, baking powder and salt were purchased from a supermarket store in Navi Mumbai. All chemicals and solvents used were of analytical grade, obtained from Sd Fine-Chem Ltd. (Mumbai, India).

\section{$2.2 \quad$ Packaging}

Food grade metallized polyester polyethylene laminate zip-lock pouches, with dimensions of $15 \mathrm{~cm}$ length x $12 \mathrm{~cm}$ width $(12 \mu \mathrm{m}$ metallized polyester, $7.5 \mu \mathrm{m}$ polyethylene), were used for packaging of biscuits and coriander leaf powder. The biscuits were placed and zip locked in the metallized polyester polyethylene laminate ziplock pouches to give air tight packs. The oxygen permeability and water vapour permeability of the metalized polyester were $1.2 \mathrm{ml} / \mathrm{m}^{2}$ day and $<1 \mathrm{~g} / \mathrm{m}^{2}$ day respectively.

\subsection{Preparation of Coriander Leaf Powder (CLP)}

Whole coriander leaves were sorted to reject over matured and insect affected portions, and then washed with water, soaked in $6 \%$ sodium hypochlorite solution $(1 \mathrm{ml} / \mathrm{L})$ for 20 minutes and dried in a tray dryer at $60 \pm 2{ }^{\circ} \mathrm{C}$ for 8 hours. The dried material was ground to a fine powder, using a grinder (Philips HL7555-00), to obtain coriander leaf powder (CLP) which passed through a BS $72(220 \mu \mathrm{m})$ mesh. The powder was then packed in metallized polyester polyethylene laminate pouches and stored at room temperature for further chemical analysis and application in biscuits. 


\subsection{Preparation of coriander supplemented biscuits}

The product formulations for the control and coriander supplemented biscuits are presented in Table 1. Control biscuits and coriander powder supplemented biscuits were prepared according to the method mentioned in the literature, with minor modifications (Galla et al., 2017). Coriander powder was supplemented at 10\%, 20\%, $30 \%$ levels in wheat flour and dough was prepared using sugar, butter, ammonium carbonate, sodium bicarbonate, baking powder, salt and water. A creaming process or premixing of butter, sugar and vanilla essence was undertaken for 2-3 minutes until a pale yellow color was obtained. Then dry flour was added to this premixed butter and sugar, with final addition of water to prepare the dough. The dough was manually kneaded for 5-7 minutes, and rested or conditioned at room temperature for 20-30 minutes. The biscuit dough was sheeted to a thickness of $3 \mathrm{~mm}$ and cut using a circular cutter of 5 $\mathrm{cm}$ diameter. The biscuits, for all four different concentrations, were arranged on a butter paper coated aluminum tray to minimize any effect of tray location and baked at $180{ }^{\circ} \mathrm{C}$ for $17-18$ minutes. Then the baked biscuits were cooled to room temperature, and packed and stored in metallized polyester polyethylene laminate ziplock pouches for further analysis and shelf life investigation. The samples were tagged as $\mathrm{CB}$ (control biscuits); (CPB-10) 10\% supplemented coriander biscuits; (CPB-20) 20\% supplemented coriander biscuits and(CPB-30) 30\% supplemented coriander biscuits. All the samples were prepared in triplicates.

\subsection{Proximate analysis of biscuits}

Moisture content and ash content of the samples were estimated by employing the standard methods of analysis (AOAC, 1995). The crude fat content of samples was determined by using Soxhlet apparatus. The method is recognized by the (AOAC, 1995). Crude protein was performed and analyzed by a certified analytical lab (Varni Analytical Laboratory Mira Road, Thane), and was estimated by the standard method of IS
7219:1973(RA-2010) using a KEL PLUS Automatic Nitrogen Estimation System. Crude fibre was performed and analyzed by a certified analytical lab (Varni Analytical Laboratory Mira Road, Thane), and was estimated by the standard method of FSSAI Manual-3. The percentage of carbohydrate content and energy value were calculated using the standard method of analysis (AOAC, 1995). The values for the proximate analysis are the average of triplicates, with standard deviation.

\subsection{Antioxidant Assays}

\section{Sample Extraction for Antioxidant Assay}

The biscuits' samples were extracted according to the method reported in the literature, with minor modifications (Chakraborty \& Bhattacharyya, 2015). 1g ground biscuit sample was extracted in $50 \mathrm{ml}$ of $60 \%$ aqueous methanol, at $40-50{ }^{\circ} \mathrm{C}$, in a beaker. The mixture was shaken vigorously for 5 minutes on a magnetic stirrer and was allowed to stand for 20 minutes at room temperature. The mixture was centrifuged at $8000 \mathrm{rpm}$ for 10 minutes. The supernatant was collected for further analysis. Fresh samples were prepared for each extraction.

\section{DPPH assay}

DPPH (2，2-Diphenyl-1-picrylhydrzyl) radical activity of coriander leaf powder (CLP), control biscuits \& coriander powder supplemented biscuits i.e. CPB: 10\%, CPB: 20\%, CPB: $30 \%$ were performed by following a method mentioned in the literature, with minor modifications (Chakraborty \& Bhattacharyya, 2015). $1 \mathrm{ml}$ of DPPH solution was mixed with $0.5 \mathrm{ml}$ of extracted sample solution. The samples were vortexed and incubated at room temperature in the dark for 30minutes. The decrease in color intensity, during incubation of the samples, was monitored at $517 \mathrm{~nm}$ in a spectrophotometer. Ascorbic acid was used as a standard. The assay was performed in triplicate. The results of scavenging activity were expressed as $\mu \mathrm{M}$ AAE (Ascorbic Acid Equivalent). 
Table 1: Product Formulation for control biscuits (CB); $10 \%$ supplemented coriander biscuits (CPB-10); $20 \%$ supplemented coriander biscuits (CPB-20) and 30\% supplemented coriander biscuits (CPB-30)

\begin{tabular}{lllll}
\hline \multirow{2}{*}{ Parameters $(\mathrm{g})$} & Control Biscuits $(\mathrm{CB})$ & \multicolumn{3}{c}{ Coriander leaf powder supplemented biscuits } \\
& & CPB:10\% & CPB:20\% & CPB:30\% \\
\hline Wheat Flour & 100 & 90 & 80 & 70 \\
Coriander Leaf Powder & - & 10 & 20 & 30 \\
Butter & 50 & 50 & 50 & 50 \\
Sugar & 36 & 36 & 36 & 36 \\
Ammonium Carbonate & 4 & 4 & 4 & 4 \\
Sodium Bicarbonate & 1 & 1 & 1 & 1 \\
Baking Powder & 2 & 2 & 2 & 2 \\
Salt (NaCl) & 1 & 1 & 1 & 1 \\
Vanilla Essence (ml) & 2 & 2 & 2 & 2 \\
Water & 60 & 60 & 60 & 60 \\
\hline
\end{tabular}

\section{Total phenolic content (TPC) assay}

Total phenolic content of coriander leaf powder (CLP), control biscuits and coriander powder supplemented biscuits i.e. CPB:10\%, CPB:20\%, CPB:30\% were performed by following a method mentioned in the literature, with minor modifications (Chakraborty \& Bhattacharyya, 2015). $0.5 \mathrm{ml}$ of extracted sample was added to $2.5 \mathrm{ml}$ of $10 \%$ Folin Ciocalteu reagent and kept at room temperature for 8 minutes. $2 \mathrm{ml}$ of $7.5 \% \mathrm{Na} 2 \mathrm{CO} 3$ was then added to the sample, vortexed and incubated at room temperature in the dark for 1 hour. The absorbance of the reaction mixture was then measured at $765 \mathrm{~nm}$ in a spectrophotometer. Gallic acid was used as the standard. Each sample was analyzed in triplicate and results expressed as $\mu \mathrm{g} / \mathrm{ml}$ GAE.

\subsection{Estimation of mineral content}

The mineral solution was prepared by dissolving the ash, obtained after ashing the samples in a muffle furnace, in diluted hydrochloric acid and then making the volume to $100 \mathrm{ml}$ with distilled water in a standard volumetric flask. Calcium in the samples was determined by the Versenate Titration (EDTA) method according to (AOAC, 1995). Phosphorus content in the samples was determined by Fiske-Subbarao method or ANSA method according to (AOAC, 1995). The absorbance of solution was taken at $510 \mathrm{~nm}$ in a spectrophotometer (Shimadzu, UV-1700 model). The assay was performed in triplicate and results expressed as the average, with standard deviation.

\subsection{Texture analysis}

Texture analysis of control biscuits and sample biscuits were carried out using a TA-XT2i texture analyzer (Stable Micro System, Ltd. in Godalming, Surrey, UK), with a $50 \mathrm{~kg}$ load cell, equipped with a $5 \mathrm{~mm}$ diameter cylindrical probe. The test speed was $0.5 \mathrm{~mm} / \mathrm{s}$, pretest speed $10 \mathrm{~mm} / \mathrm{s}$, probe reversing speed $10 \mathrm{~mm} / \mathrm{s}$ and trigger force was $15 \mathrm{~g}$ and the distance travelled by the probe inside the sample was $1 \mathrm{~mm}$. The average of three values, with standard deviation, was taken for each set of samples.

\subsection{Sensory analysis}

The control biscuits and coriander powder supplemented biscuits were subjected to sensory evaluation by 15 panelists $(7$ males and 8 females), aged between 20 to 35 years, who had earlier experience in quality evaluation of bakery products. Also the panelists were trained via six pre-test sessions according to Pasqualone et al. (2011). The parameters evaluated were appearance, aroma, texture, taste and overall acceptability. The coded samples were served in 
clean white plates. The panelists scored for different parameters using a 9-point Hedonic scale:9 for like extremely, 8-like very good, 7-like good, 6-like moderately, 5-neither like nor dislike, 4-dislike moderately, 3- dislike fairly, 2-dislike very much and 1 for dislike extremely (Amerine, Pangborn \& Roessler, 2013).

\subsection{Shelf life analysis}

The analysis of control and coriander leaf supplemented biscuits was carried for 21 days, at an interval of 7 days, under room temperature(30$35{ }^{\circ} \mathrm{C}$ ) storage, at a relative humidity of $60-65 \%$. The samples were stored in the metallized polyester polyethylene laminate pouches for different storage intervals to check the efficiency of packaging. The samples were checked every 7 days for the moisture content, mineral content, antioxidant activity, total phenolic content, texture, color analysis, organoleptic evaluation and microbiological analysis throughout the 21 days of storage.

\section{Microbiological Analysis}

The total microbial loads of the control biscuits and the coriander leaf supplemented biscuit samples were determined for 21 days, at an interval of 7 days, by the method as described by APHA (2005). The microbiological quality of control biscuit and coriander leaf supplemented biscuit samples was determined by enumerating total viable organisms, which includes the total aerobic count of bacteria and molds. Nutrient agar was used for total viable count and potato dextrose agar was used for the presence of yeasts and molds.1g of biscuit samples were mixed with $9 \mathrm{ml}$ of sterile saline $(0.85 \%)$ to obtain $10^{-1}$ dilution. Further serial dilution was made up-to $10^{-4}$ using a fresh sterile pipette every time. The spread plate technique was used to assess the microbial population. $0.1 \mathrm{ml}$ of each dilution was poured plated onto prepared, sterile and dried nutrient agar plates for total viable count and potato dextrose agar plates for yeasts and molds. The sample was spread by using a sterile glass spreader in circular movements in different directions for $10 \mathrm{sec}$. After inoculation, the plates were incubated in an incubator at 37 ${ }^{\circ} \mathrm{C}$ for 48 hours for total viable count and for 3-5 days for yeasts and molds.

\subsection{Statistical analysis}

All data were expressed as means \pm standard errors of triplicate measurements and analysed by SPSS for Windows (ver. 16.0). One-way analysis of variance (ANOVA): Post Hoc multiple comparison were carried out to test significant differences. Statistical comparisons between variables were performed with the Least Square Differential method (LSD). Differences were considered significant at $\mathrm{p}<0.05$.

\section{Results and discussion}

\subsection{Proximate composition}

The mineral content and antioxidant activity of coriander leaf powder are presented in Table 2 . The Calcium, Iron and Phosphorus content in coriander leaf powder was found to be 2805.46 $\mathrm{mg} / 100 \mathrm{~g}, 42.1 \mathrm{mg} / 100 \mathrm{~g}$ and $44.36 \mathrm{mg} / 100 \mathrm{~g}$ respectively. The determined scavenging activity and Total phenolic content of CLP were 93.34 $\mu \mathrm{M} / \mathrm{mlAAE}$ and $40.43 \mu \mathrm{g} / \mathrm{mlGAE}$. The nutritional composition of $\mathrm{CB}$ and $\mathrm{CPB}-10-30 \%$ is presented in Table 2. CPB-30\% possessed high quantities of protein $(17.84 \%)$ and fiber $(15.9 \%)$. Increasing addition of coriander (10-30\%) enhanced the protein and fiber in biscuits as compared to the control. A decrease in fat content was observed as the concentration of coriander in the biscuits increased and hence the least amount of fat was seen in CPB-30\% (22.71\%). The carbohydrate content in the given samples ranged from $40.18 \%-54.68 \%$ and was highest in the control biscuit $(54.68 \%)$. It was also observed that the energy value of samples ranged from 428.67 kcal to $470.42 \mathrm{kcal}$. The highest energy value was recorded in the control biscuit $(470.42 \mathrm{kcal})$. The difference in proximate composition of the value added biscuits developed from dehydrated coriander leaf powder was basically due to the difference in the proximate composition of coriander powder. 


\subsection{Shelf Life Study of coriander supplemented biscuits}

\section{Effect of storage period on moisture content}

Moisture content data for CB, CPB-10\%, 20\% and $30 \%$ are presented in Figure 1. The slight increase in moisture content in optimized biscuits, supplemented with coriander powder, as compared to the control biscuit might be due to the higher water binding capacity of dehydrated coriander powder. A similar increase in moisture content of biscuits by addition of spinach powder was reported by Galla et al. (2017). The moisture content in a food product influences the water activity and hence the shelf life of the product. The lower the moisture content in the product, the longer the shelf life and quality of the product. The moisture content over the storage period increased for $\mathrm{CB}, \mathrm{CPB}-10 \%$, CPB$20 \%$, CPB-30\%. The maximum moisture content for CB, CPB-10\%, CPB- $20 \%$, CPB-30\% was seen on day $21(1.3 \pm 0.02,1.43 \pm 0.06,1.59 \pm 0.015$, $1.7 \pm 0.05)$ with the lowest on day $0(1.09 \pm 0.03$, $1.22 \pm 0.07,1.38 \pm 0.02,1.46 \pm 0.025)$ respectively. The increase in moisture content might be due to the hygroscopic nature of biscuits, storage environment or the ineffective moisture impermeability of the packaging material. A similar increase inmoisture content in wheat defatted coconut flour was seen throughout the storage period (Nadarajah \& Mahendran, 2015).

\section{Effect of storage period on scavenging activity}

The scavenging activity of biscuits during storage is shown in Figure 3. The figure shows that the antioxidant activity increased with the supplementation of CLP in the biscuits. Initially, the highest scavenging activity was seen in CPB$30 \%$ samples $(84.26 \%)$ which decreased to $78 \%$ on day 21. Throughout the storage period, all samples decreased slightly in their antioxidant activity. The scavenging activity of fresh product on day 0 was $21.16 \pm 0.15,78.33 \pm 0.3,80.36 \pm 0.35$ and $84.26 \pm 0.25$ for CB, CPB- $10 \%$, CPB- $20 \%$ and CPB-30\% biscuits respectively. Whereas, the scavenging activity on day 21 was found to be $17 \pm 0.15,70 \pm 0.15,75.36 \pm 0.15$ and $78.26 \pm 0.3$ for CB, CPB-10\%, CPB-20\% and CPB-30\% biscuits respectively. Storage period significantly affected the antioxidant activity of coriander biscuits. Due to ineffective oxygen impermeability of the packaging material, the effect in antioxidant activity was observed. A similar decreasing trend in antioxidant activity during storage was observed in defatted coconut cookies due to the oxidation of unsaturated fatty acids with atmospheric oxygen and moisture uptake (Nadarajah \& Mahendran, 2015). Hence, the results of this assay indicated a decrease in the scavenging activity, with an increase in days of storage.

\section{Effect of storage period on Total Phenolic content}

The changes in total phenolic content for all the samples are shown in Figure 4. It was observed that the phenolic content increased in the biscuits supplemented with CLP. The highest phenolic content was estimated in CPB-30\% samples on day $0(5.09 \mu \mathrm{g} / \mathrm{ml}$ GAE $)$ and this decreased to $4.6 \mu \mathrm{g} / \mathrm{ml}$ GAE on day 21. Throughout the storage period, all samples slightly decreased in their antioxidant activity. The results of this assay indicated the slight decrease in the phenolic content in the $\mathrm{CB}, \mathrm{CPB}-10 \%$, CPB$20 \%$, CPB-30\% biscuits on day21 (1.03 \pm 0.05 , $3.5 \pm 0.1,3.9 \pm 0.1,4.6 \pm 0.1)$ as compared to the fresh products $(1.43 \pm 0.20,4.15 \pm 0.03,4.60 \pm 0.01$, $5.09 \pm 0.01)$ respectively. Storage period significantly affected the phenolic content of coriander biscuits in agreement with the results of scavenging activity.

\section{Texture measurements}

The data for the textural measurements are presented in the Figure 2. A slight difference was observed in the hardness of the biscuits throughout the storage period as compared to the fresh product. The hardness went on increasing as the concentration of CLP increased. A similar increase in texture values of biscuits by addition of spinach powder was reported by Galla et al. (2017). The values for hardness of the biscuits decreased throughout the storage 
The fortification of biscuits with coriander leaf powder $\mid 231$

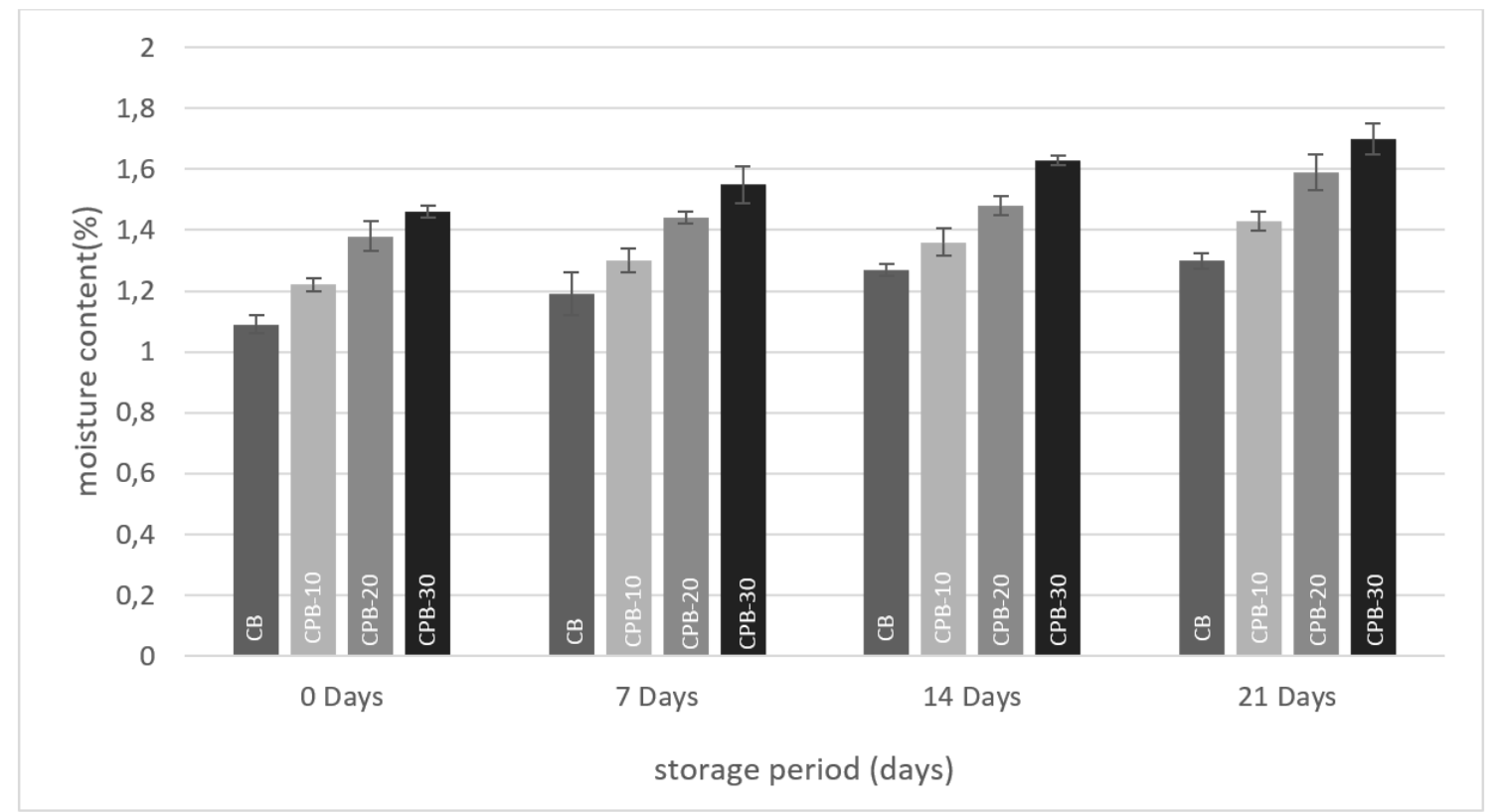

Figure 1: Effect of coriander powder on moisture content (means of three replicates \pm standard deviation) control biscuits (CB); $10 \%$ coriander supplemented biscuits (CPB-10); $20 \%$ coriander supplemented biscuits (CPB-20); 30\% coriander supplemented biscuits (CPB-30) during storage at room temperature.

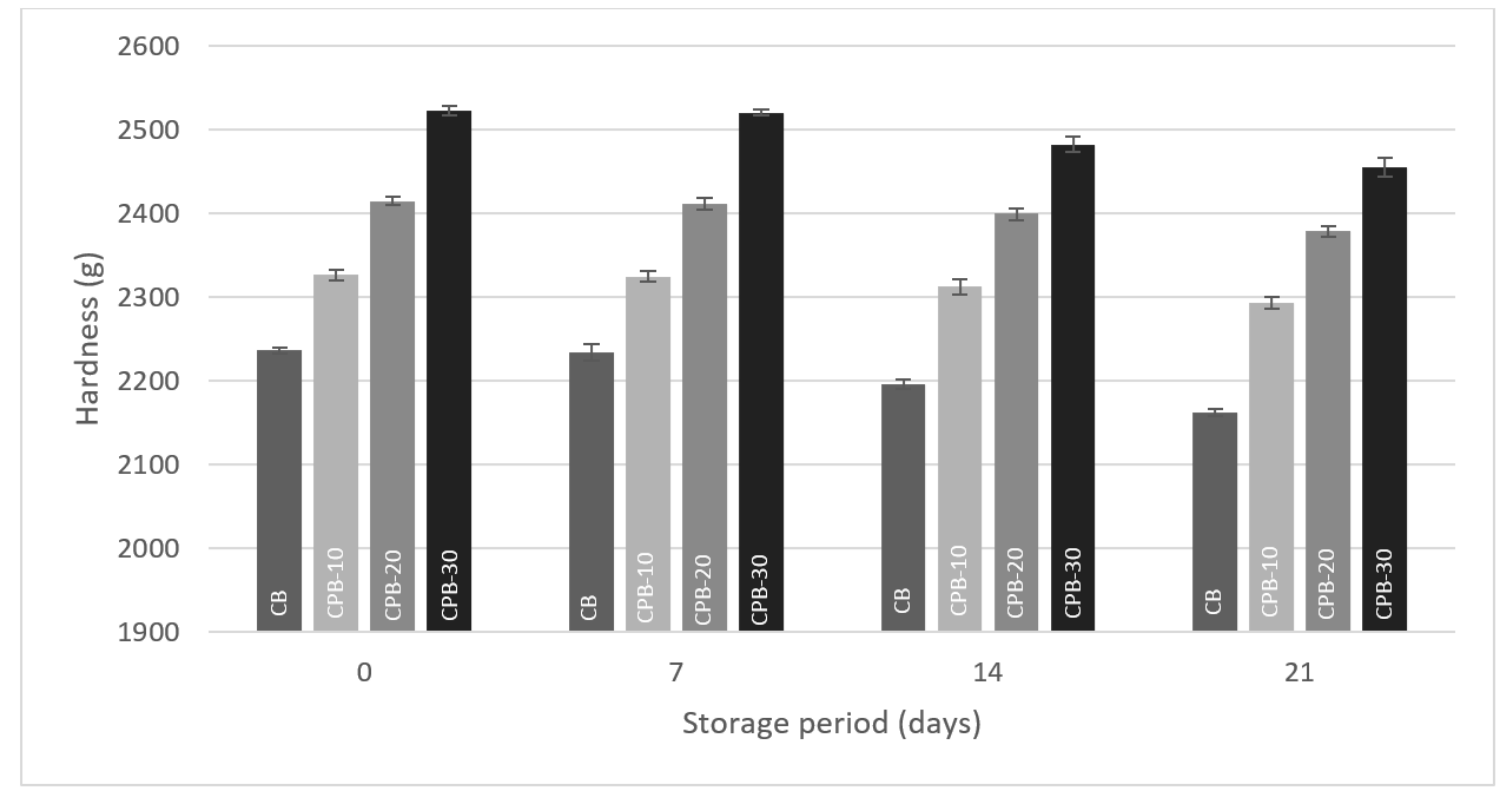

Figure 2: Effect of coriander powder on texture (means of three replicates \pm standard deviation) control biscuits (CB); $10 \%$ coriander supplemented biscuits (CPB-10); $20 \%$ coriander supplemented biscuits (CPB-20); 30\% coriander supplemented biscuits (CPB-30) during storage at room temperature. 
Table 2: Nutritional composition of control biscuits (CB); $10 \%$ supplemented coriander biscuits (CPB10); $20 \%$ supplemented coriander biscuits (CPB-20) and30\% supplemented coriander biscuits (CPB-30), mineral composition and antioxidant activity of coriander leaf powder (CLP)

\begin{tabular}{lllll}
\hline \multirow{2}{*}{ Nutritional composition (\%) } & \multirow{2}{*}{ Control $(\mathrm{CB})$} & \multicolumn{3}{l}{ coriander leaf powder supplemented biscuits } \\
& & CPB:10\% & CPB:20\% & CPB:30\% \\
\hline Moisture & $1.09 \pm 0.3 \mathrm{a}$ & $1.22 \pm 0.1 \mathrm{a}$ & $1.38 \pm 0.3 \mathrm{a}$ & $1.46 \pm 0.2 \mathrm{a}$ \\
Ash & $2.61 \pm 0.1 \mathrm{a}$ & $3.16 \pm 0.2 \mathrm{~b}$ & $3.68 \pm 0.1 \mathrm{c}$ & $4.21 \pm 0.3 \mathrm{~d}$ \\
Fat & $23.72 \pm 0.3 \mathrm{a}$ & $23.84 \pm 0.7 \mathrm{a}$ & $23.16 \pm 0.6 \mathrm{a}$ & $22.71 \pm 0.5 \mathrm{a}$ \\
Crude Protein & $9.52 \pm 0.1 \mathrm{a}$ & $13.49 \pm 0.8 \mathrm{~b}$ & $15.40 \pm 0.5 \mathrm{c}$ & $17.84 \pm 0.4 \mathrm{~d}$ \\
Crude Fibre & $8.31 \pm 0.4 \mathrm{a}$ & $11.41 \pm 0.3 \mathrm{~b}$ & $13.91 \pm 0.06 \mathrm{c}$ & $15.90 \pm 0.7 \mathrm{~d}$ \\
Carbohydrates & $54.68 \pm 0.7 \mathrm{a}$ & $46.76 \pm 0.3 \mathrm{~b}$ & $42.86 \pm 0.4 \mathrm{c}$ & $40.18 \pm 0.8 \mathrm{~d}$ \\
Energy (kcal/100g) & $470.42 \pm 1.3 \mathrm{a}$ & $456.2 \pm 2.1 \mathrm{~b}$ & $439.85 \pm 0.9 \mathrm{c}$ & $428.67 \pm 1.6 \mathrm{~d}$ \\
\hline
\end{tabular}

\begin{tabular}{llllll}
\hline & \multicolumn{3}{c}{ Mineral content } & \multicolumn{2}{c}{ Antioxidant activity } \\
\cline { 2 - 6 } & $\begin{array}{l}\text { Calcium } \\
(\mathrm{mg} / 100 \mathrm{~g})\end{array}$ & $\begin{array}{l}\text { Iron } \\
(\mathrm{mg} / 100 \mathrm{~g})\end{array}$ & $\begin{array}{l}\text { Phosphorus } \\
(\mathrm{mg} / 100 \mathrm{~g})\end{array}$ & $\begin{array}{l}\text { DPPH(AAE, } \\
\mu \mathrm{M} / \mathrm{ml})\end{array}$ & $\begin{array}{l}\text { TPC(GAE, } \\
\mu \mathrm{g} / \mathrm{ml})\end{array}$ \\
\hline Coriander Leaf Powder & $2805.46 \pm 0.4 \mathrm{a}$ & $42.1 \pm 0.1 \mathrm{~b}$ & $44.36 \pm 0.5 \mathrm{c}$ & $93.34 \pm 0.1 \mathrm{~d}$ & $40.43 \pm 0.3 \mathrm{e}$ \\
\hline
\end{tabular}

Values are average of triplicate analysis with \pm SD. DPPH: 2, 2-Diphenyl-1-picrylhydrzyl; AAE: Ascorbic Acid Equivalent. TPC: Total Phenolic Content; GAE: Gallic Acid Equivalent. Different small letters in a row indicate differences for control and supplemented coriander biscuits $(\mathrm{P}<0.05)$.

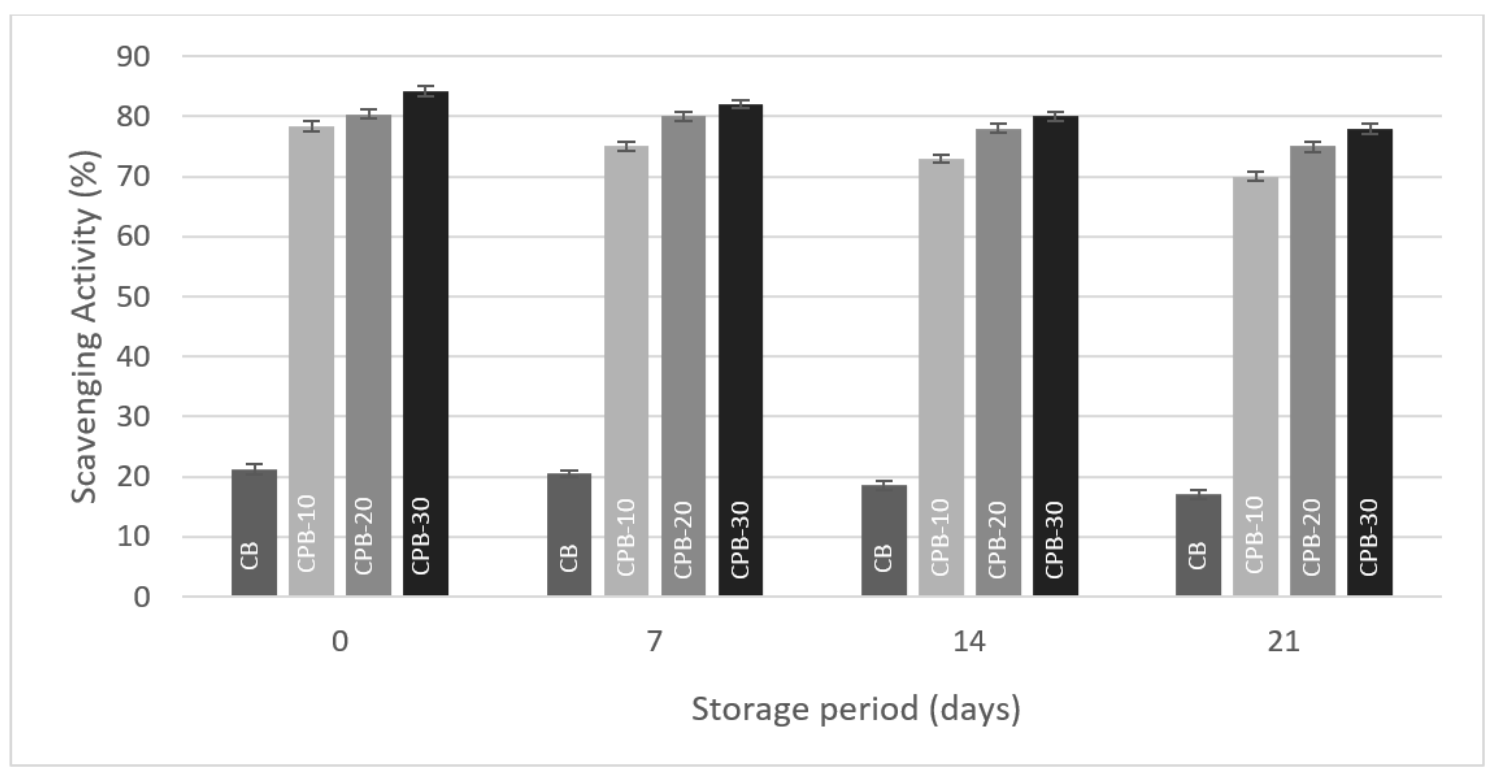

Figure 3: Effect of coriander powder on scavenging activity (means of three replicates \pm standard deviation) control biscuits (CB); $10 \%$ coriander supplemented biscuits (CPB-10); $20 \%$ coriander supplemented biscuits (CPB-20); 30\% coriander supplemented biscuits (CPB-30) during storage at room temperature. 
The fortification of biscuits with coriander leaf powder $\mid 233$

Table 3: Effect of coriander powder on sensory attributes (means of three replicates \pm standard deviation) of control biscuits (CB); $10 \%$ coriander supplemented biscuits (CPB-10); $20 \%$ coriander supplemented biscuits (CPB-20); 30\% coriander supplemented biscuits (CPB-30) during storage at room temperature.

\begin{tabular}{|c|c|c|c|c|c|}
\hline \multirow{2}{*}{ Sensory attributes } & \multirow{2}{*}{$\begin{array}{l}\text { Storage } \\
\text { days }\end{array}$} & \multirow{2}{*}{$\begin{array}{l}\text { Control } \\
\text { Biscuits } \\
(\mathrm{CB})\end{array}$} & \multicolumn{3}{|c|}{ Coriander supplemented biscuits } \\
\hline & & & CPB- $10 \%$ & CPB- $20 \%$ & CPB-30\% \\
\hline \multirow[t]{4}{*}{ Appearance } & 0 & $8.6 \pm 0.3^{a}$ & $8.3 \pm 0.2^{a}$ & $8.1 \pm 0.3^{a}$ & $7.3 \pm 0.3^{b}$ \\
\hline & 7 & $8.3 \pm 0.1^{a}$ & $8.0 \pm 0.3^{a}$ & $7.6 \pm 0.4^{a}$ & $7.1 \pm 0.2^{a}$ \\
\hline & 14 & $7.8 \pm 0.2^{a}$ & $7.6 \pm 0.2^{a}$ & $7.5 \pm 0.2^{a}$ & $6.6 \pm 0.6^{b}$ \\
\hline & 21 & $7.5 \pm 0.4^{a}$ & $7.1 \pm 0.4^{a}$ & $7.1 \pm 0.1^{a}$ & $6.2 \pm 0.4^{b}$ \\
\hline \multirow[t]{4}{*}{ Aroma } & 0 & $8.4 \pm 0.2^{a}$ & $8.1 \pm 0.3^{a}$ & $8.1 \pm 0.6^{a}$ & $7.7 \pm 0.2^{a}$ \\
\hline & 7 & $8.1 \pm 0.2^{a}$ & $7.7 \pm 0.5^{a}$ & $7.5 \pm 0.4^{a}$ & $7.4 \pm 0.4^{a}$ \\
\hline & 14 & $7.6 \pm 0.4^{a}$ & $7.2 \pm 0.3^{a}$ & $7.0 \pm 0.2^{a}$ & $6.9 \pm 0.5^{a}$ \\
\hline & 21 & $7.2 \pm 0.5^{a}$ & $6.8 \pm 0.2^{a}$ & $6.6 \pm 0.4^{a}$ & $6.2 \pm 0.6^{a}$ \\
\hline \multirow[t]{4}{*}{ Texture } & 0 & $8.6 \pm 0.4^{a}$ & $8.4 \pm 0.4^{a}$ & $8.0 \pm 0.5^{a}$ & $7.4 \pm 0.4^{a}$ \\
\hline & 7 & $8.2 \pm 0.3^{a}$ & $8.1 \pm 0.3^{a}$ & $7.7 \pm 0.6^{a}$ & $7.1 \pm 0.5^{a}$ \\
\hline & 14 & $7.5 \pm 0.2^{a}$ & $7.4 \pm 0.5^{a}$ & $7.3 \pm 0.5^{a}$ & $6.8 \pm 0.2^{a}$ \\
\hline & 21 & $7.1 \pm 0.3^{a}$ & $7.2 \pm 0.4^{a}$ & $7.0 \pm 0.3^{a}$ & $6.5 \pm 0.6^{a}$ \\
\hline \multirow[t]{4}{*}{ Taste } & 0 & $8.5 \pm 0.4^{a}$ & $8.4 \pm 0.4^{a}$ & $8.1 \pm 0.5^{a}$ & $7.1 \pm 0.2^{b}$ \\
\hline & 7 & $8.1 \pm 0.3^{a}$ & $8.2 \pm 0.2^{a}$ & $7.7 \pm 0.2^{b}$ & $6.6 \pm 0.4^{c}$ \\
\hline & 14 & $7.8 \pm 0.2^{a}$ & $7.6 \pm 0.3^{a}$ & $7.3 \pm 0.5^{a}$ & $6.3 \pm 0.3^{b}$ \\
\hline & 21 & $7.6 \pm 0.3^{a}$ & $7.5 \pm 0.4^{a}$ & $7.0 \pm 0.3^{a}$ & $6.1 \pm 0.4^{b}$ \\
\hline \multirow[t]{4}{*}{ Overall Acceptability } & 0 & $8.4 \pm 0.4^{a}$ & $8.1 \pm 0.5^{a}$ & $8.0 \pm 0.5^{a}$ & $7.2 \pm 0.2^{b}$ \\
\hline & 7 & $8.1 \pm 0.3^{a}$ & $7.6 \pm 0.4^{a}$ & $7.6 \pm 0.4^{a}$ & $6.8 \pm 0.4^{b}$ \\
\hline & 14 & $7.7 \pm 0.3^{a}$ & $7.2 \pm 0.4^{a}$ & $7.1 \pm 0.3^{a}$ & $6.4 \pm 0.3^{b}$ \\
\hline & 21 & $7.3 \pm 0.4^{a}$ & $6.8 \pm 0.5^{a}$ & $6.5 \pm 0.6^{a}$ & $6.0 \pm 0.1^{a}$ \\
\hline
\end{tabular}

*Values are average of triplicate analysis with \pm SD; CB: Coriander Biscuits Different small letters in a row indicate differences for control and coriander supplemented biscuits $(\mathrm{P}<0.05)$

period. The hardness of $\mathrm{CB}, \mathrm{CPB}-10 \%$, CPB$20 \%$, CPB-30\% biscuits on day 0 were $2236.3 \pm 4$, $2326.6 \pm 6.2,2414.6 \pm 4.09$ and $2522.667 \pm 5.04$ respectively, compared to $2162.3 \pm 4.07,2293 \pm 7.08$, $2379 \pm 6.5$, and $2455 \pm 10.98$ respectively on day 21 . This may be due to variation in the moisture content of the control and coriander supplemented biscuits throughout the shelf life of the biscuits.

\section{Sensory Analysis}

Sensory scores for all attributes were quite affected, as the days of storage increased, as shown in Table 3. Darkness in the samples increased with an increase in CLP content of biscuits. There was a negligible difference in tex- ture and taste of all the samples when compared to fresh products. Overall acceptability was slightly higher for fresh products as compared to products stored until 21 days. This may be due to the non- enzymatic browning reaction and fat oxidation. It was reported that moisture uptake and gas exchange were causes of off odour development in biscuits (Berger \& Fisek, 1970). The sensory score was slightly affected by appearance when products were stored for 21 days. All the samples showed slight change in color up to 21 days as per the results presented in Table 3. Aroma refers to the intensity associated with coriander powder and ingredients sufficiently heated to caramelize some starches and sugars. Sensory score for aroma ranged from 7.7 


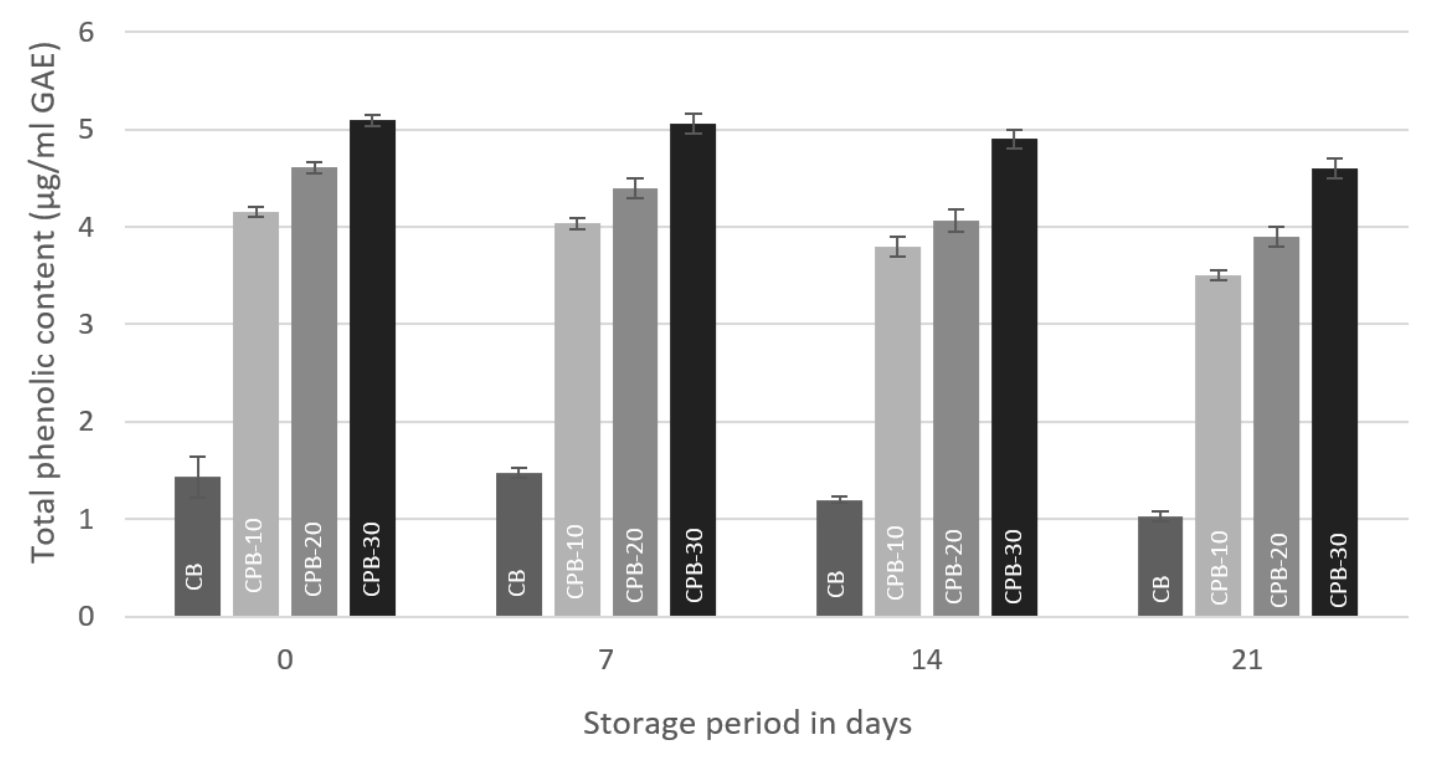

Figure 4: Effect of coriander powder on total phenolics content (means of three replicates \pm standard deviation) control biscuits (CB); $10 \%$ coriander supplemented biscuits (CPB-10); $20 \%$ coriander supplemented biscuits (CPB-20); 30\% coriander supplemented biscuits (CPB-30) during storage at room temperature.

Table 4: Effect of coriander powder on mesophilic aerobics and yeasts and molds (means of three replicates \pm standard deviation) of control biscuits (CB); $10 \%$ coriander supplemented biscuits (CPB10); $20 \%$ coriander supplemented biscuits (CPB-20); 30\% coriander supplemented biscuits (CPB-30) during storage at room temperature

\begin{tabular}{|c|c|c|c|c|c|}
\hline $\begin{array}{l}\text { Storage } \\
\text { in days }\end{array}$ & $\begin{array}{l}\text { Microbial load } \\
\left(\mathrm{x} 10^{3} \mathrm{cfu} / \mathrm{ml}\right)\end{array}$ & $\begin{array}{l}\text { Control } \\
\text { (CB) }\end{array}$ & CPB- $10 \%$ & CPB- $20 \%$ & CPB-30\% \\
\hline \multirow[t]{2}{*}{0} & TPC & $\mathrm{x}$ & $\mathrm{x}$ & $\mathrm{x}$ & $\mathrm{x}$ \\
\hline & Yeasts \& molds & $\mathrm{x}$ & $\mathrm{x}$ & $\mathrm{x}$ & $\mathrm{x}$ \\
\hline \multirow[t]{2}{*}{7} & $\mathrm{TPC}$ & 0.2 & 0.25 & 0.2 & 0.13 \\
\hline & Yeasts \& molds & $\mathrm{x}$ & $\mathrm{x}$ & $\mathrm{x}$ & $\mathrm{x}$ \\
\hline \multirow[t]{2}{*}{14} & TPC & 0.37 & 0.32 & 0.33 & 0.28 \\
\hline & Yeasts \& molds & $\mathrm{x}$ & $\mathrm{x}$ & $\mathrm{x}$ & $\mathrm{x}$ \\
\hline \multirow[t]{2}{*}{21} & $\mathrm{TPC}$ & 0.44 & 0.2 & 0.4 & 0.4 \\
\hline & Yeasts \& molds & $\mathrm{x}$ & $\mathrm{x}$ & $\mathrm{x}$ & $\mathrm{x}$ \\
\hline
\end{tabular}

*TPC- Total Plate Count; $\mathrm{x}-$ no visible growth; cfu- colony forming unit 
to 8.4 for all the freshly prepared samples. The minimum score was obtained for sample CPB$30 \%$, and the maximum was obtained for CB. The score for texture of the biscuits was slightly decreased after 14 and 21 days when compared to the texture of the fresh products. There was a decrease in the taste score during the storage period of the $\mathrm{CB}$, CPB- $10 \%, 20 \%$ and $30 \%$ biscuits. The overall acceptability depends on color, flavor and taste score of the products. The overall acceptability score ranged from 8.4 to7.3, 8.1 to $6.8,8.0$ to 6.5 and 7.2 to 6.0 for the control, CPB-10\%, CPB-20\% and CPB-30\% samples. The least score was observed for the CPB - 30\% sample. The values presented in the table clearly indicate that the highest overall acceptability score was for the control sample, followed by CPB-10\%, CPB-20\% and CPB-30\%.

\section{Microbiological Analysis}

The results for microbiological analysis of the samples are shown in Table 4. There was no fungal growth observed on potato dextrose agar media in the coriander powder supplemented biscuits which were packed in the metallized polyethylene zip lock batches during the entire storage period of 21 days. Lack of fungal growth might be due to effective packaging. The bacterial growth was observed in the control, CPB$10 \%$, CPB- $20 \%$ and CPB-30\% biscuits on storage for 7,14 and 21 days. Total viable count results showed negligible growth on all the storage days. This is an indication that the biscuits were prepared under good hygienic condition and the integrity of the packaging material used was not compromised. Therefore, it can be concluded that the products remained safe for consumption up to 21 days of the storage period.

\section{Conclusions}

It has been observed that dehydrated coriander powder could be safely employed as a protein, mineral and fibre source in biscuits at $20 \%$ level. The scavenging activity of CPB-20\% biscuits up to $81 \%$ and calcium content almost $1202 \mathrm{mg}$ calcium $/ 100 \mathrm{~g}$ was achieved by the addition of $20 \%$ of dehydrated coriander. A reduction in fat con- tent in the biscuits can be highlighted with increased addition of coriander. It is found that the sensory score and the overall acceptability of the coriander biscuits were acceptable up to $20 \%$ level. The coriander leaves can be readily selected and utilized as a remarkable food ingredient to formulate a wide range of products considering its valuable nutrient composition, with noticeable amounts of both macronutrients (carbohydrate and protein) and micronutrients (minerals and antioxidants). Presence of heat stable antioxidants increase the potential of the bioactive compounds based coriander leaf to become a valuable food ingredient. Hence, coriander leaves may be used as a potential source of food flavoring and antioxidants.

\section{Acknowledgements}

The authors greatly appreciate Dr. Debjani Dasgupta, Director of School of Biotechnology and Bioinformatics, Navi Mumbai for her constant encouragement throughout the work.

\section{References}

Aissaoui, A., Zizi, S., Israili, Z. H. \& Lyoussi, B. (2011). Hypoglycemic and hypolipidemic effects of Coriandrum sativum L. in meriones shawi rats. Journal of Ethnopharmacology, 137(1), 652-661. doi:10.1016/j.jep. 2011.06.019

Amerine, M. A., Pangborn, R. M. \& Roessler, E. B. (2013). Principles of sensory evaluation of food. Elsevier.

AOAC. (1995). Official Methods of Analysis 16th edn. Association of official AnalyticalChemists, Washington, DC.

APHA. (2005). Standard methods for the Examination of Water and Wastewater, 21st Edition.American Public Health Association, Washington, D.C.

Berger, J. \& Fisek, M. H. (1970). Consistent and inconsistent status characteristics and the determination of power and prestige orders. Sociometry, 287-304. 
Chakraborty, K. \& Bhattacharyya, S. (2015). Evaluation of in vitro antioxidant potential of green tea (Camelia sinensis) infusions with leaves collected from different heights of darjeeling hill, west bengal. Euro J. Biomed Pharm Sci, 2, 736-749.

Dhanapakiam, P., Joseph, J. M., Ramaswamy, V. K., Moorthi, M. \& Kumar, A. S. (2008). The cholesterol lowering property of coriander seeds (Coriandrum sativum): Mechanism of action. Journal of Environmental Biology, 29(1), 53-56.

Emamghoreishi, M. \& Heidari-Hamedani, G. (2005). Sedativehypnotic activity of extracts and essential oil of coriander seeds. Iran. J. Med. Sci, 31.

Galla, N. R., Pamidighantam, P. R., Karakala, B., Gurusiddaiah, M. R. \& Akula, S. (2017). Nutritional, textural and sensory quality of biscuits supplemented with spinach (Spinacia oleracea L.) International Journal of Gastronomy and Food Science, 7, 20-26. doi:10.1016/j.ijgfs.2016.12.003

Giarnetti, M., Paradiso, V. M., Caponio, F., Summo, C. \& Pasqualone, A. (2015). Fat replacement in shortbread cookies using an emulsion filled gel based on inulin and extra virgin olive oil. $L W T$ - Food Science and Technology, 63(1), 339-345. doi:10.1016/j. lwt.2015.03.063

Hooda, S. \& Jood, S. (2005). Organoleptic and nutritional evaluation of wheat biscuits supplemented with untreated and treated fenugreek flour. Food Chemistry, 90(3), 427-435. doi:10.1016/j.foodchem.2004.05. 006

Jabeen, Q., Bashir, S., Lyoussi, B. \& Gilani, A. H. (2009). Coriander fruit exhibits gut modulatory, blood pressure lowering and diuretic activities. Journal of Ethnopharmacology, 122(1), 123-130. doi:10.1016/j. jep.2008.12.016

Jelodar, G., Mohsen, M. \& Shahram, S. (2007). Effect of walnut leaf, coriander and pomegranate on blood glucose and histopathology of pancreas of alloxan induced diabetic rats. African Journal of Traditional Complementary and Alternative Medicines, 4(3), 299-305.
Kaium, A. (2013). Yield and yield contributes of coriander (Coriandrum Sativum L.) as influenced by spacing and variety (Doctoral dissertation, Department of Agricultural Botany, Sher-e-Bangla Agricultural University).

Krystyjan, M., Gumul, D., Ziobro, R. \& Korus, A. (2015). The fortification of biscuits with bee pollen and its effect on physicochemical and antioxidant properties in biscuits. LWT - Food Science and Technology, 63(1), 640-646. doi:10.1016/j.lwt.2015.03. 075

Melo, E. D., Mancini, J. \& Guerra, N. B. (2005). Characterization of antioxidant compounds in aqueous coriander extract (Coriandrum sativum L.) LWT - Food Science and Technology, 38(1), 15-19. doi:10. 1016/j.lwt.2004.03.011

Nadarajah, S. \& Mahendran, T. (2015). Influence of storage conditions on the quality characteristics of wheat-defatted coconut flour biscuits packed in metalized polypropylene. International Journal of Engineering Research and Technology (IJERT). 4.

Pasqualone, A., Piergiovanni, A. R., Caponio, F., Paradiso, V. M., Summo, C. \& Simeone, R. (2011). Evaluation of the technological characteristics and bread-making quality of alternative wheat cereals in comparison with common and durum wheat. Food Science and Technology International, 17(2), 135-142. doi:10.1177/1082013210381547

Pasqualone, A., Bianco, A. M. \& Paradiso, V. M. (2013). Production trials to improve the nutritional quality of biscuits and to enrich them with natural anthocyanins. CytaJournal of Food, 11(4), 301-308. doi:10 . 1080/19476337.2012.753113

Rajeshwari, C. U. \& Andallu, B. (2011). Oxidative stress in niddm patients: Influence of coriander (Coriandrum sativum) seeds. Research Journal of Pharmaceutical, Biological and Chemical Sciences, 2, 31-41.

Yamsaengsung, R., Berghofer, E. \& Schoenlechner, R. (2012). Physical properties and sensory acceptability of cookies made from chickpea addition to white wheat or whole wheat flour compared to gluten-free amaranth or buckwheat flour. International 
The fortification of biscuits with coriander leaf powder $\mid 237$

Journal of Food Science and Technology, 47(10), 2221-2227. doi:10.1111/j.13652621.2012.03092.x

Zaker, M. D., Aleem \& T. R., G. (2012). Effects of defatted soy flour incorporation on physical, sensorial and nutritional properties of biscuits. Journal of Food Processing 83 Technology, 03. doi:10.4172/2157-7110. 1000149 